Full-text Available Online at www.ajol.info and www.bioline.org.br/ja
J. Appl. Sci. Environ. Manage. Sept 2013

Vol. 17 (3) 357-362

\title{
Chemical Characterization, Anti inflammatory and Analgesic Properties of Jatropha Multifida Root Bark
}

\section{*11ABIODUN FALODUN; IGHODARO IGBE; OSAYEMWENRE ERHARUYI; ONYINYE JACINTA AGBANYIM}

\author{
${ }^{1}$ Department of Pharmaceutical Chemistry, Faculty of Pharmacy, University of Benin, Benin City, Nigeria. \\ ${ }^{2}$ Department of Pharmacology and Toxicology, Faculty of Pharmacy, University of Benin, Benin City, Nigeria. \\ faloabi@uniben.edu,ighodaro.igbe@uniben.edu,osayemwenre.erharuyi@uniben.edu
}

Tel: +2348073184488

Key words: anti-inflammatory, analgesic, Jatropha multifida, methanol extract.

\begin{abstract}
Jatropha multifida is used in African folk medicine for the treatment of infection, pain, fever, various inflammatory conditions, tumor and tumor related diseases. The present study investigated the phytochemical constituents of the powdered root bark using established standard procedures. The methanol root bark extract at doses of 100 $\mathrm{mg} / \mathrm{kg}, 200 \mathrm{mg} / \mathrm{kg}$ and $400 \mathrm{mg} / \mathrm{kg}$ was subjected to evaluation of anti-inflammatory and analgesic activities in experimental animal models. The anti-inflammatory activity was estimated by measuring the mean thickness in carrageenan-induced hind paw oedema in Wistar albino rats. The analgesic activity was assessed by acetic acid-induced writhing in Swiss albino mice. Indomethacin $(10 \mathrm{mg} / \mathrm{kg})$ and acetyl salicylic acid $(100 \mathrm{mg} / \mathrm{kg})$ were used as standards in the anti-inflammatory and analgesic assay respectively. Phytochemical investigations reveal the presence of alkaloids, tannins, glycosides, saponins and flavonoids. The extract at a dose of $400 \mathrm{mg} / \mathrm{kg}$ significantly $(\mathrm{P}<0.01)$ reduced paw thickness in rat compared to control. There was a dose dependent decrease in writhings which was significant $(\mathrm{P}<0.05)$ at $400 \mathrm{mg} / \mathrm{kg}$ compared to control. The results therefore suggest that $J$. Multifida root bark has anti-inflammatory and analgesic activities which further substantiate its use in folk medicine.@ JASEM
\end{abstract}

\section{http://dx.doi.org/10.4314/jasem.v17i3.3}

The importance of plants to man cannot be over emphasized. They are an essential part in his survival particularly when food and shelter are considered (Kimba, 1984). Some plants, apart from serving as food have also been known to exhibit medicinal properties. About $80 \%$ of the population in the third world nations depend on traditional medicine for primary health care and about $85 \%$ of these traditional medicine are plant based (Farnsworth and Soejarto, 1985).

Despite the numerous chemical compounds now synthesized in the laboratory and screened for activity that might be of therapeutic value, natural products, especially those derived from plants are still the most important sources of new drugs (Odugbemi, 2006). Over $40 \%$ of current prescription medicine contains chemicals derived from plants (Moerman, 1996). Hence, when we take well packaged medicines today, it is important to note that we might be taking a processed plant product.

* Correspondence Author: faloabi@ uniben.edu
The phytochemical investigation of a plant may involve extraction of the plant material, separation and isolation of constituents of interest, characterization of the isolated compound, investigation of the biosynthetic pathways to particular compounds and qualitative evaluation (Evans, 2002). Such isolates are mostly secondary metabolites such as alkaloids, anthraquinone, tannins, glycosides, flavonoids, terpenoids and components of volatile oils (Evans, 2002). The occurrences of these constituents vary in medicinal plants as they react to changing environmental conditions. It is these secondary metabolites that have biological actions and which can be modified to produce drugs (Anyasor et al., 2011; Edeoga and Gomina, 2000).

In spite of progress made in scientific research in the past few years, treatment of many diseases still remain a problem, chronic inflammation and pain is one of the world's major health problem (Li et al., 
2003; Adedapo et al., 2008). Therefore, the research into plant with claimed anti-inflammatory and analgesic properties in folklore may be seen as a logical research strategy for the quests for new antiinflammatory and analgesic agents (Gupta et al., 2006).

Jatropha multifida Linn. Commonly called coral bush is a tree or shrub belonging to the family euphorbiaceae (Dehgan, 1982; Padua et al., 1999). The plant is used in traditional medicine for the treatment of various diseases. In West Africa, especially in Nigeria, the leaves are used in the treatment of oral thrush, constipation and fever (Kayode and Omotoyinbo, 2008; Kirtikar and Basu, 1981). Latex from the leaf and poultices of the roots are employed as anthelminthic, treatment of would infection and various inflammatory skin conditions (Shu et al., 2008; Aiyelaagbe, 2001). Methanol, ethyl acetate, chloroform and $n$-hexane extract of the roots have been shown to have antibacterial activity particularly against Bacillus subtilis and Staphylococcus aureus (Aiyelaagbe, 2001). The cytotoxic effect on tumor cells of compounds extracted from the stem have been reported (Das et al., 2009).

\section{MATERIALS AND METHODS}

Collection of plant material: Fresh roots of Jatropha multifida were collected from Ojavun village in Owan East Local Government area of Edo State, Nigeria in May, 2012. The plant was identified and authenticated in the Forest Research Institute of Nigeria, Ibadan and a voucher specimen number FHI109573 is deposited.

Preparation of plant material and extraction: The fresh roots were air dried and subjected to size reduction to get a coarse powder using a mechanical grinder. The powdered sample was preserved in moisture-free, air tight container. Powdered sample $(760 \mathrm{~g})$ was macerated in methanol $(2.5 \mathrm{~L})$ at room temperature for one week. The methanol extract was concentrated in vacuu using a rotary evaporator.

Phytochemical screening: Simple chemical tests to detect the presence of alkaloids, tannins, saponins, carbohydrates, glycosides and flavonoids were done in accordance with standard methods (Evans, 2002; Sofowora, 1982; Stahl, 1973).

Powdered sample $(5 \mathrm{~g})$ was boiled with $75 \mathrm{~mL}$ of distilled water for 30 minutes. The solution was filtered hot and allowed to cool. The filtrate obtained was used to carry out the tests.
Quantitative parameters: The following quantitative parameters were carried out using standard methods (African Pharmacopoeia (1986; AOAC, 1984).

Alcohol soluble extractive value: Powdered sample (5 g) was macerated with $100 \mathrm{~mL}$ of absolute ethanol shaking frequently for the first $6 \mathrm{~h}$ and left to stand for $18 \mathrm{~h}$. The mixture was filtered and $20 \mathrm{~mL}$ of the filtrate evaporated to dryness and further dried to a constant weight in an oven at $105^{\circ} \mathrm{C}$. The alcohol extractive value was calculated with reference to the initial weight of the powdered sample and expressed as percentage.

Water soluble extractive value: Powdered sample (5 g) was macerated with $100 \mathrm{~mL}$ of chloroform water (1:400) shaking frequently for the first $6 \mathrm{~h}$ and left to stand for $18 \mathrm{~h}$. The mixture was filtered and $20 \mathrm{~mL}$ of the filtrate evaporated to dryness and further dried to a constant weight in an oven at $105{ }^{\circ} \mathrm{C}$. The water extractive value was calculated with reference to the initial weight of the powdered sample and expressed as percentage.

Moisture content / Water loss on drying: The powdered plant material ( $2 \mathrm{~g})$ was oven-dried at 105 ${ }^{\circ} \mathrm{C}$ until a constant weight was reached. The percentage moisture content was determined for six replicates according to the formulae below.

Moisture Content $(\%)=\frac{\text { Weight Loss }}{\text { Initial Weight of Sample }} \times 100 \%$

Total ash: $2 \mathrm{~g}$ portions of the powdered plant material were weighed separately into twelve crucibles. The crucibles with the contents were heated in the furnace at $600{ }^{\circ} \mathrm{C}$ for $6 \mathrm{~h}$. The furnace was off and temperature allowed to drop, the crucibles were removed and cooled in a desiccator and reweighed. The percentage ash was calculated for six replicates.

$$
\text { Percentage Total Ash }(\%)=\frac{W-Z}{N} \times 100 \%
$$

Where;

$\mathrm{W}=$ Weight of the crucible and ash,

$\mathrm{Z}=$ Weight of empty crucible,

$\mathrm{N}=$ Weight of sample.

Acid insoluble ash: The ash from experiment above was transferred into a beaker containing $25 \mathrm{~mL}$ of dilute $\mathrm{HCl}$ and boiled for $5 \mathrm{~min}$, filtered through an ash less filter paper, the filter paper with the residue was folded into a small cone and transferred into the crucible and then heated in the furnace until the filter

\section{ABIODUN FALODUN; IGHODARO IGBE; OSAYEMWENRE ERHARUYI; ONYINYE JACINTA AGBANYIM}


paper was completely ashed. The weight of the residue was determined and the percentage acid insoluble ash calculated for six replicates based on the initial weight of the air dried powdered sample.

Acid Insoluble Ash Value $=\frac{\text { Weight of Residue }}{\text { Initial Wt of the Sample }} \times 100 \%$

Water insoluble ash: The ash from the total ash experiment was boiled in $25 \mathrm{~mL}$ of distilled water for 5 min and filtered through an ash less filter paper. The filter paper and the residue was folded into a small cone and placed in the crucible and heated until the filter paper was completely ashed. The percentage water insoluble ash was determined for six replicates.

Acid Insoluble Ash Value $=\frac{\text { Weight of Residue }}{\text { Initial Wt of the Sample }} \times 100 \%$

Animals: All experiments were performed using male Swiss albino mice $(30-40 \mathrm{~g})$ and Wistar rats (146-269 g) of either sex. The animals were maintained under standard environmental conditions in the Animal House of the Department of Pharmacology and Toxicology, Faculty of Pharmacy, University of Benin. They were fed with standard rodent pellets (Bendel feeds and flour mill, Ewu, Edo state, Nigeria) and allowed free access to water. All animals were handled in accordance with internationally accepted principles guiding the use and handling of experimental animals.

Anti-inflammatory activit:y Carrageenan-induced paw oedema: Wistar albino rats (146-269 g) were divided into five groups of five animals per group. Each animal in group I was treated with the vehicle (distilled water) per oral to serve as a control. Animals in groups II, III and IV were treated with $100 \mathrm{mg} / \mathrm{kg}, 200 \mathrm{mg} / \mathrm{kg}$ and $400 \mathrm{mg} / \mathrm{kg}$ body weight of the extract respectively while group $\mathrm{V}$ animals received indomethacin $(10 \mathrm{mg} / \mathrm{kg}$ body weight $)$ by same route. After one hour of treatment, acute inflammation was induced by sub plantar injection of $0.1 \mathrm{~mL}$ of $1 \%$ carrageenan in the left hind paw (Winter et al., 1962). Paw thickness was measured at $0,1,2$ and 3 hours following carrageenan administration using a vernier calliper (Thambi et al., 2006).

Analgesic activity: Acetic acid-induced writhing in mice: Swiss albino mice $(30-40 \mathrm{~g})$ were divided into five groups of five animals per group. Animals in group I received distilled water per oral to serve as control. Groups II, III and IV were administered the extract at doses of $100 \mathrm{mg} / \mathrm{kg}, 200 \mathrm{mg} / \mathrm{kg}$ and $400 \mathrm{mg} / \mathrm{kg}$ body weight respectively per oral. Group $\mathrm{V}$ animals were treated with acetylsalicylic acid (100 $\mathrm{mg} / \mathrm{kg}$ body weight) by same route. After one hour of treatment, animals were administered $0.6 \%$ acetic acid $(10 \mathrm{ml} / \mathrm{kg}$ body weight) intraperitoneally. The number of writhing movements was counted for 30 minutes (Koster et al, 1959).

Statistical analysis: Results were expressed as Mean \pm SEM. Significance of difference between means was determined by student's t-test and $\mathrm{p}$ values $<0.05$ were considered significant.

\section{RESULTS AND DISCUSSION}

Phytochemical screening of the plant material revealed that alkaloids, tannins, flavonoids, glycosides and saponins are present (table 1). Antiinflammatory activities of many plants have been attributed to their high sterol/triterpene (Ahmad et al., 1983) or flavonoids contents (Silva et al., 2005; parmar and Ghosh, 1978).

Table 1: Phytochemical composition of the root bark of Jatropha multifida.

\begin{tabular}{ll}
\hline Phytochemical & Inference \\
\hline Carbohydrate & + \\
Glycosides & + \\
Alkaloids & + \\
Tannins & + \\
Saponins & + \\
Flavonoids & + \\
\hline
\end{tabular}

indicates presence of compound.

The values for the proximate analysis are presented in table 2. In this study, proximate analysis was carried out for the purpose of authentication of the crude powdered plant material. The moisture content shows the susceptibility of crude plant materials to microbial attack especially fungi, and also to degradation due to hydrolysis of the crude powdered sample. The maximum permissible range for a crude drug is between $6-8 \%$ (AOAC, 1984). A moisture content of $9.48 \pm 1.28 \%$ (table 2 ) obtained from this study suggest that the crude plant material could be susceptible to microbial degradation or hydrolytic break down of the chemical constituents. The total ash is a measure of the non-volatile inorganic constituents remaining after ashing. The acid insoluble ash is a measure of the sandy matter in crude drug samples (African pharmacopoeia, 1986).

\section{ABIODUN FALODUN; IGHODARO IGBE; OSAYEMWENRE ERHARUYI; ONYINYE JACINTA AGBANYIM}


Table 2: Proximate parameters of the root bark of Jatropha multifida.

\begin{tabular}{l|l}
\hline Parameter & Value (\%) \\
\hline Alcohol soluble extractive & $0.64 \pm 0.02$ \\
Water soluble extractive & $1.40 \pm 0.02$ \\
Moisture content & $9.48 \pm 1.28$ \\
Total ash & $10.65 \pm 0.03$ \\
Acid insoluble ash & $5.98 \pm 0.03$ \\
Water insoluble ash & $8.08 \pm 0.02$ \\
& \\
\hline
\end{tabular}

In the carrageenan-induced paw oedema (figure 1) the methanol root bark extract of J. multifida at a dose of $400 \mathrm{mg} / \mathrm{kg}$ body weight significantly $(\mathrm{P}<$ 0.01) inhibited paw oedema within three hours of the inflammatory response compared to the control. The anti-inflammatory effects were comparatively less than that of indomethacin

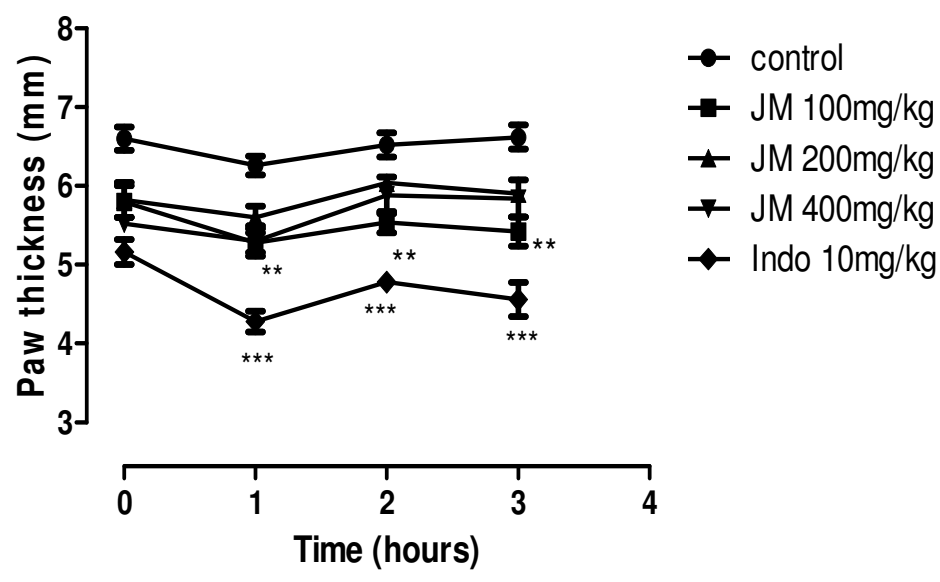

Fig. 1: Effect of methanol extract of Jatropha multifida on carrageenan-induced paw oedema in rats. $* * \mathrm{P}<$ 0.01 , ***P $<0.001$ as compared to the control $(\mathrm{n}=5)$. JM = Jatropha multifida, Indo = Indomethacin.

Carrageenan-induced hind paw oedema is an established experimental model for acute inflammation especially in natural products. The development of carrageenan-induced oedema is biphasic (Vinegar et al., 1987); the first phase occurs within one hour of carrageenan administration and this is attributed to the release of cytoplasmic enzymes, histamine and serotonin, from mast cells. The second phase (over one hour) is mediated by an increased release of prostaglandins, arachidonate metabolites, neutrophil migration, release of oxygen free radicals, proteolytic enzymes, as well as other neutrophil-derived mediators (Bouriche et al., 2003). The oedema maintained between the first and second phase is due to kinin-like substances, especially bradykinin (Vinegar et al., 1987).
The methanol extract of Jatropha multifida root bark reduced the carrageenan-induced paw oedema but the reduction was only significant at the highest dose of $400 \mathrm{mg} / \mathrm{kg}$ body weight when compared to the control. The anti-inflammatory effect was sustained in the first, second as well as in the continuous phase of the inflammatory process, thus suggesting that the extract maybe inhibiting the release of histamine, prostaglandins as well as other inflammatory mediators (Ferreira et al., 1974). The effect of the extract on the later phase indicates that the extract may be acting by inhibition of bradykinin release and/or its vascular permeability promoting action. This effect is similar to that produced by nonsteroidal anti-inflammatory drugs (NSAID) such as indomethacin (Wu, 2003). 
Table 3 shows the effects of the methanol extract on acetic acid-induced writhing in mice. There was a dose dependent decrease in the number of writhings. The extract (400 mg/kg body weight) produced a significant $(\mathrm{P}<0.05)$ decrease in the number of writhings compared to the control.

Table 3: Effect of methanol extract of Jatropha multifida on acetic acid-induced mouse writhing

\begin{tabular}{ll}
\hline Treatment & $\begin{array}{l}\text { Number of writhings } \\
\text { after 30 min } \\
\text { (Mean } \pm \text { SEM) }\end{array}$ \\
\hline Control & $63.00 \pm 9.56$ \\
Jatropha multifida $(100 \mathrm{mg} / \mathrm{kg})$ & $48.00 \pm 10.42$ \\
Jatropha multifida $(200 \mathrm{mg} / \mathrm{kg})$ & $51.30 \pm 12.2$ \\
Jatropha multifida $(400 \mathrm{mg} / \mathrm{kg})$ & $39.75 \pm 13.0 *$ \\
Acetylsalicylic acid $(100 \mathrm{mg} / \mathrm{kg})$ & $18.30 \pm 5.82 * *$ \\
$* \mathrm{P}<0.05, * * \mathrm{P}<0.01$ as compared to the control $(\mathrm{n}=5)$.
\end{tabular}

The acetic acid-induced writhing in mice is widely used for the evaluation of peripheral anti-nociceptive activity (Gene et al., 1998). It is very sensitive and able to detect anti-nociceptive effects of compounds at dose levels that may appear inactive in other methods (Bentley et al., 1981). The method has been associated with prostanoids in general, e.g. increased levels of $\mathrm{PGE}_{2}$ and $\mathrm{PGF}_{2 \alpha}$ in peritoneal fluids (Derardt et al., 1980), as well as lipooxygenase products (Dhara et al., 2000). Oral administration of the methanol extract of Jatropha multifida was shown to reduce writhings induced by $0.6 \% \mathrm{v} / \mathrm{v}$ acetic acid significantly at $400 \mathrm{mg} / \mathrm{kg}$ body weight and the reduction was sustained throughout the 30 minutes period.

Conclusion: The result of the present study have demonstrated that Jatropha multifida root bark has anti-inflammatory and analgesic activities thus providing pharmacological evidence of it claimed folkloric use. Further work is required to establish its exact mode of action and possible isolation of the bioactive constituent(s).

Acknowledgements: The authors are grateful to the Department of Pharmaceutical Chemistry and the Department of Pharmacology and Toxicology, Faculty of Pharmacy, University of Benin, Benin City, Nigeria for use of the laboratory facility. The STEP-B project is gratefully acknowledged.

\section{REFERENCES}

Adedapo A.A., Sofidiya M.O., Maphosa V., Moyo B., Masika P.J. and Afolayan A.J. (2008). Antiinflammatory and analgesic activities of the aqueous extract of Cussonia paniculata stem bark. Rec. Nat. Prod. 2(2):46-53.

African Pharmacopoeia (1986). Vol. $21^{\text {st }}$ ed., OAU/STRC publications: pp 128-144.

Ahmad M.M., Quresh S., Shah A., Qazi N.S., Rao R.M. and Albakiri M. (1983). Anti-inflammatory activity of Caralluma tuberculata alcoholic extract. Fitoterapia 46:357-360.

Aiyelaagbe O.O. (2001). Antibacterial activity of Jatropha multifida roots. Fitoterapia 72(5):5446.

Anyasor G.N., Aina D.A., Olushola M. and Aniyikaye A.F. (2011). Phytochemical constituent, proximate analysis, antioxidant, antibacterial and wound healing properties of leaf extracts of Chromolaena Odorata. Ann. Bio. Res. 2(2):441-451.

AOAC. (1984). Official method of analysis. Association of Official Analytical Chemists. Washinghton D.C: pp 1112-1114.

Bentley G.A., Newton S.H. and Starr J. (1981). Evidence for action of morphine and enkephalins and sensory nerve endings in the mouse peritoneum. Br. J. Pharmacol. 73: 325-332.

Bouriche H., Selloum L., Tigrine C. and Boudoukha C. (2003). Effect of Cleoma Arabica leaf extract on rat paw oedema and human neutrophil migration. Pharm. Biol. 41:10-15.

Das B., Reddy K.R., Ravikanth B., Raju T.V., Sridhar B.M., Khan P.U. and Rao J.V. (2009). Multifidone: A novel cytotoxic lathyrane-type diterpene having an unusual six-membered A ring from Jatropha multifida. Bioorganic and Medicinal Chemistry Letters 19(1):77-79.

Dehgan B. (1982). Proc. Fla. State. Hort. Soc. 95:277-280.

Derardt R., Jongney S., Delvalcee F. and Falhout M. (1980). Release of prostaglandins $\mathrm{E}$ and $\mathrm{F}$ in an algogenic reaction and its inhibition. Eur. J. Pharmacol. 51:17-24.

Dhara A.K., Suba V., Sen T., Pal S. and Chaudhuiri A.K. (2000). Preliminary studies on the antiinflammatory and analgesic activity of methanol fraction of the root of Tragia involucrate. J. Ethnopharmacol. 72:265-268.

\section{ABIODUN FALODUN; IGHODARO IGBE; OSAYEMWENRE ERHARUYI; ONYINYE JACINTA AGBANYIM}


Edeoga H.O. and Gomina A. (2000). Nutritional values of some non-conventional leafy vegetable in Nigeria. J. Econ. Tax. Bot. 24:7-13.

Evans W.C. (2002). Trease and Evans Pharmacognosy, $15^{\text {th }}$ ed., Churchill Livingstone Harcourt publishers Limited, London: pp 221336.

Farnsworth N.R. and Soejarto D.D. (1985). Potential consequences of plant extinction in the united states on the current and future availability of prescription drugs. J. Econ. Bot. 39(3):231-240.

Ferreira S.H., Flower R.J., Parsons M.F. and Vane J.R. (1974). Reduction of the inflammatory response in rats immunized against prostaglandins. Prostaglandins 8(5):433-437.

Gene R.M., Segura L., Adzet T., Marin E. and Inglesias J. (1998). Heterotheca inuloides: antiinflammatory and analgesic effects. J. Ethno. 60:157-162.

Gupta M., Mazumder U.K., Gomathi P. and Selvan V.T. (2006). Antinflammatory evaluation of leaves of Plumeria acuminata BMC Compl. and Alt. Med. 6:36.

Kayode J. and Omotoyinbo M.A. (2008). Res. J. Bot. 3(3):107-115.

Kimba J.W. (1984). Biology $4^{\text {th }}$ Edition A.W Publishing Company. pp 476-506.

Kirtikar and Basu (1981). Indian Medicinal Plant 4:2240-2247.

Koster R., Anderson M. and De Beer E.J. (1959). Acetic acid for analgesic screening. Fed. Proc. 18:412.

Li R.W., Myers S.P., Leach D.N., Lin G.D. and Leach G. (2003). A cross cultural study: antiinflammatory activity of Australian and Chinese plants. J. Ethnopharmacol. 85:25-32.

Moerman D.E. (1996). An Analysis of the Food Plants and Drug Plants of Native North America J. Ethnopharmacol. 52:1-22.
Odugbemi T. (2006). Outlines and Pictures of Medicinal Plants from Nigeria. pp 1-85.

Padua L.S., Bunyapraphatsara N. and Lemmens R.H.M.J. (1999). Plant Resources of South-East Asia No (12)1. Medicinal and poisonous plant 1: Leiden, Backhuys Publishers.

Parmar N.S. and Ghosh M.M.N. (1978). Current trends in flavonoid research. Indian J. Pharm. 12:213-228.

Shu M.F.S., Bingtao L. and Gilbert M.G. (2008). Fl. China 11:268-269.

Silva G.N., Martins F.R. and Matheus M.E. (2005). Investigation of anti-inflammatory and antinociceptive activities of Lantana trifolia. J. Ethnopharmacol. 100:254-259.

Sofowora A. (1982). Screening Plants for Bioactive Agents. In Medicinal Plants and Traditional Medicine in Africa. Spectrum Books Ltd., Ibadan: pp 128-161.

Stalh E. (1973). Drug analysis by chromatography and Microscopy. A Practical Supplement to Pharmacopoeias, $1^{\text {st }}$ ed., Ann Arbor, Michigan: pp 219-224.

Thambi P.T., Kuzhivelil B., Sabu M.C. and Jolly C.I. (2006). Antioxidant and anti-inflammatory activities of flowers of Tabernaemontana coronaria (I) R. Br. Indian J. Pharm. Sci. 68:352-355.

Vinegar R., Truax J.F., Selph J.H., Johnson P.R., Venable, A.L. and Mckenzie K.K. (1987). Pathway to carrageenan-induced inflammation in the hind limb of the rat. Fed. Proc. 46:118-126.

Winter C.A., Risley E.A. and Nuss G.W. (1962). Carrageenan-induced edema in hind paw of rats as an assay for anti-inflammatory drugs. Proc. Soc. Exp. Bio. Med. 111:544-547.

Wu K.K. (2003). Aspirin and other cyclooxygenase inhibitors: new therapeutic insights. Seminar Vascular Med. 3:107-112.

\section{ABIODUN FALODUN; IGHODARO IGBE; OSAYEMWENRE ERHARUYI; ONYINYE JACINTA AGBANYIM}

